\title{
The correlation of age, gender and drug dose with side effects of isotretinoin in patients with acne vulgaris
}

\author{
Akne vulgaris nedeniyle isotretinoin kullanan hastalarda ilaç yan etkilerinin yaș, \\ cinsiyet ve ilaç dozu ile ilișkisi
}

\section{Dursun Türkmen}

Malatya Training and Research Hospital, Clinic of Dermatology, Malatya, Turkey

\begin{abstract}
Background and Design: Acne vulgaris is a chronic inflammatory disease of pilosebaceous unit. Oral isotretinoin is the most effective agent that has been used for many years in acne treatment. The purpose of our study was to determine the side effects of the isotretinoin and to examine the correlation between these side effects, and age, gender and drug dose.

Materials and Methods: One hundred forty nine patients with moderate or severe acne vulgaris (age between: 14-34 years) using isotretinoin were included. Eight patients discontinued treatment for various reasons. Daily isotretinoin dose was started as less than $0.5 \mathrm{mg} / \mathrm{kg} / \mathrm{day}$. A cumulative dose of at least $120 \mathrm{mg} / \mathrm{kg}$ was targeted in all patients. The patients were assessed in terms of side effects on a monthly basis.

Results: Of the 141 patients who have completed the treatment, 106 (75.2\%) were female and $35(24.8 \%)$ were male. Cheilitis was seen in $100 \%$, xeroderma in $66 \%$, photophobia in $44.7 \%$, mild epistaxis in $42.6 \%$, and xerophthalmia in $36.9 \%$ of the patients. Lumbar pain was seen in $41.1 \%$, myalgia in $29.1 \%$, arthralgia in $19.1 \%$, headache in $13.5 \%$ of the patients. Serum lipid levels increased in $20.6 \%$ of the patients, while liver enzyme levels increased in $7.8 \%$ of the patients. Myalgia and lumbar pain was more common in females $(p=0.045, p=0.019$, respectively). Patients who received higher than $0.5 \mathrm{mg} / \mathrm{kg} /$ day dose had more xerosis, myalgia and triggering acne complaints ( $p=0.004$, $p=0.001, p=0.012$, respectively). Myalgia were found to be more common in patients who were older than 20 years old $(p=0.003)$.

Conclusion: Because the use of isotretinoin is a long-lasting treatment method, patient compliance is of paramount importance. Knowing how frequent side effects will occur in different patients groups and informing the patients beforehand will increase patients' confidence towards to physician and minimize the compliance problems.
\end{abstract}

Keywords: Acne vulgaris, isotretinoin, side effects, myalgia, epistaxis

\section{Öz}

Amaç: Akne vulgaris, pilosebase ünitenin kronik enflamatuvar bir hastalığıdır. Oral izotretinoin akne tedavisinde uzun yıllardır kullanılan en etkili tedavi ajanıdır. Çalışmamızda ilacın yan etkilerini tespit etmeyi ve bunların yaş, cinsiyet ve ilaç dozu ile bağlantısını araştırmayı amaçladık. Gereç ve Yöntem: Çalışmamızda, yaşları 14-34 arasında değişen, izotretinoin kullanan, 149 orta veya şiddetli akne vulgarisli hasta yer aldı. Sekiz hasta çeşitli sebeplerle tedaviye devam etmedi. Günlük izotretinoin dozu 0,5 mg/kg'nin altında başlandı. Tüm hastalarda en az $120 \mathrm{mg} /$ kg kümülatif doz hedeflendi. Hastalar yan etkiler açısından aylık olarak değerlendirildi.

Bulgular: Tedaviyi tamamlayan 141 hastanın 106'sı $(\% 75,2)$ kadın, 35'i (\%24,8) erkekti. Hastaların \%100'ünde keilitis, \%66'sında kseroderma, $\% 44,7^{\prime}$ sinde fotofobi, \%42,6'sında hafif burun kanaması, \%36,9'unda göz kuruluğu görüldü. Bel ağrısı hastaların \%41,1'inde, kas ağrısı $\% 29,1^{\prime}$ inde, eklem ağrısı \%19,1'inde ve baş ağrısı \%13,5'inde görüldü. Serum lipit düzeyleri hastaların \%20,6'sında, karaciğer enzim düzeyleri ise hastaların \%7, 'inde yüksekti. Kas ağrısı ve bel ağrııı kadın hastalarda daha yüksekti (sırasıyla; $p=0,045, p=0,019$ ). illaç dozu 0,5 mg/ $\mathrm{kg} / \mathrm{günün}$ üzerinde olan hastalarda kseroderma, kas ağrısı ve akne tetiklenmesi daha fazlaydı (sırasıyla; $p=0,004, p=0,001, p=0,012$ ). Yirmi yaşından büyük hastalarda kas ağıısı daha fazlaydı $(p=0,003)$.

Sonuç: İzotretinoin tedavisi uzun süreli bir tedavi olduğu için hasta uyumu önem arz etmektedir. Hangi hasta grubunda hangi yan etkilerin ne sıklıkta olduğunu iyi bilmek ve hastaları önceden bu konuda bilgilendirmek hastanın hekime olan güvenini arttıracaktır ve uyum problemini minimuma indirecektir.

Anahtar Kelimeler: Akne vulgaris, izotretinoin, yan etkiler, kas ağrısı, epistaksis

Address for Correspondence/Yazıșma Adresi: Dursun Türkmen MD, Malatya Training and Research Hospital, Clinic of Dermatology, Malatya, Turkey Phone: +90 5302236955 E-mail: dursunturkmen44@gmail.com Received/Geliş Tarihi: 27.08.2019 Accepted/Kabul Tarihi: 21.04.2020 ORCID: orcid.org/0000-0001-9076-4669 


\section{Introduction}

Acne vulgaris is a chronic inflammatory disease of pilosebaceous unit. It is the most common skin disease which influences almost $85 \%$ of the population between 12-14 years of age. Although acne vulgaris is a self-limiting disease, it should be treated since it can leave scars and cause psychological problems ${ }^{1}$. Isotretinoin, approved by the Food and Drug Administration in 1982, is the most effective treatment agent used for many years in the treatment of severe acne, it is the only agent that suppresses sebum production, provides long-term remission and is effective against all factors that play a role in acne pathogenesis ${ }^{2-7}$. The conventional standard dose recommended for isotretinoin is $0.5-1$ $\mathrm{mg} / \mathrm{kg} /$ day for the first 16-32 weeks until a target cumulative dose of $120 \mathrm{mg} / \mathrm{kg}^{8}$. Side effects of isotretinoin are known, but there is no much data on age, sex, and drug dose relationship. The purpose of my study was to find out common side effects of the isotretinoin and to examine the association between these side effects and age, gender and drug dose.

\section{Materials and Methods}

Patients with moderate and severe acne vulgaris who did not benefit from other acne treatments and did not receive any topical or systemic treatment for acne during the past year were included in our study. A total of 149 patients between the ages of 14 and 34 years between July 2017 and July 2019 were included in the study. The study was conducted in line with the Declaration of Helsinki. Ethics board approval was taken from Malatya Clinical Researches Ethics Board (approval number: 2018/27, date: 27.03.2018) and written consent was taken from all participants in the study. Female patients were informed about contraception, as required. Before the beginning of treatment, the patients were given leaflets which included information about the drug. All patients and their family members were informed about common side effects. During the treatment period, patients were assessed monthly, possible side effects were examined and the patients were reinformed about the emerging side effects. Daily isotretinoin dose was started as less than $0.5 \mathrm{mg} / \mathrm{kg}$. During the follow-up, isotretinoin was given to 39 patients (27.7\%) as less than $0.5 \mathrm{mg} / \mathrm{kg} /$ day, while 102 patient $(72.3 \%$ ) was given $0.5-1.0 \mathrm{mg} / \mathrm{kg} /$ day. At least a cumulative dose of $120 \mathrm{mg} / \mathrm{kg}$ was targeted in all patients. Before the treatment started, routine biochemistry, lipid profile, hemogram tests were studied in all patients and beta-human chorionic gonadotropin test in female patients. Patients who had a normal baseline blood tests results underwent blood tests in every two months. Patients who had an abnormal baseline blood tests results underwent blood tests monthly.

\section{Statistical Analysis}

SPSS (SPSS for Windows, Version 22.0, SPSS Inc, U.S.A) program was used for statistical assessment. Continuous variables were given as numbers and percentages, while categorical variables were given as means \pm standard deviations. Chi-square test was used for the comparison of categorical variables. A p-value less than 0.05 level was accepted as statistically significant.

\section{Results}

There were a total of 149 patients included in the study. We stopped treatment in two patients (one due to sacroileitis and one due to elevated liver enzymes). Six patients discontinued treatment because they were concerned about the various side effects of the drug [epistaxis (2), elevated liver enzymes (1), elevated lipids (1), excessive xerosis (1), irritability (1)]. One hundred and forty-one patients were checked regularly until the end of treatment.

Of the 141 patients who have completed the treatment, 106 (75.2\%) were females and $35(24.8 \%)$ were males. The ages of the patients

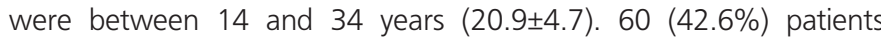
had only face involvement, 69 (48.9\%) patients had face and body involvement, 10 (7.1\%) patients had face, body and scalp involvement. In $26(18.4 \%)$ of the patients, a first degree relative had history of isotretinoin use (Table 1). In the six-month follow-up, complete recovery was found in 127 (90.1\%) patients, while partial recovery was found in $14(9.9 \%)$ patients and the treatment was prolonged.

Of the mucocutaneous side effects, cheilitis was seen in all (100\%) patients. Xeroderma was seen in $93(66 \%)$ patients, photophobia in $63(44.7 \%)$ patients, mild epistaxis in $60(42.6 \%)$ patients, and xerophthalmia in 52 (36.9\%) patients. In addition, 62 (44\%) patients were found to have an increase in acne severity in the first 45 days of the treatment (Table 2).

Table 1. Demographic characteristics of the study patients $(n=141)$

\begin{tabular}{|c|c|c|}
\hline & Number & Percentage \\
\hline \multicolumn{3}{|l|}{ Gender } \\
\hline Male & 35 & 24.8 \\
\hline Female & 106 & 75.2 \\
\hline \multicolumn{3}{|c|}{ The use of isotretinoin in the family } \\
\hline Yes & 26 & 18.4 \\
\hline No & 115 & 81.6 \\
\hline \multicolumn{3}{|l|}{ Site of acne } \\
\hline Face & 60 & 42.6 \\
\hline Face and body & 69 & 48.9 \\
\hline Face, body and scalp & 10 & 7.1 \\
\hline Face and scalp & 1 & 0.7 \\
\hline Body & 1 & 0.7 \\
\hline \multicolumn{3}{|l|}{ Drug dose } \\
\hline$<0,5 / \mathrm{kg} /$ day & 39 & 27.7 \\
\hline$\geq 0,5 / \mathrm{kg} /$ day & 102 & 72.3 \\
\hline \multicolumn{3}{|l|}{ Recovery month } \\
\hline Partial recovery & 14 & 9.9 \\
\hline Complete recovery $1^{\text {st }}$ month & 3 & 2.1 \\
\hline Complete recovery $2^{\text {nd }}$ month & 11 & 7.8 \\
\hline Complete recovery $3^{\text {rd }}$ month & 35 & 24.8 \\
\hline Complete recovery $4^{\text {th }}$ month & 50 & 35.5 \\
\hline Complete recovery $5^{\text {th }}$ month & 16 & 11.3 \\
\hline Complete recovery $6^{\text {th }}$ month & 12 & 8.5 \\
\hline
\end{tabular}




\begin{tabular}{|c|c|c|}
\hline & Number & Percentage \\
\hline Cheilitis & 141 & 100 \\
\hline Xerosis & 93 & 66 \\
\hline Exacerbation of acne lesions & 62 & 44 \\
\hline Photophobia & 63 & 44.7 \\
\hline Mild epistaxis & 60 & 42.6 \\
\hline Xerophthalmia & 52 & 36.9 \\
\hline Hair loss & 11 & 7.8 \\
\hline
\end{tabular}

Table 3. Systemic side effects in patients receiving isotretinoin

\begin{tabular}{|l|l|l|}
\hline & Number & Percentage \\
\hline Lumbar pain & 58 & 41.1 \\
\hline Myalgia & 41 & 29.1 \\
\hline Arthralgia & 27 & 19.1 \\
\hline Headache & 19 & 13.5 \\
\hline Psychological side effects & 34 & 24.1 \\
\hline Decreased appetite & 23 & 16.3 \\
\hline Increased appetite & 8 & 5.7 \\
\hline Nausea & 2 & 1.4 \\
\hline Weakness & 1 & 0.7 \\
\hline Shortness of breath & 1 & 0.7 \\
\hline Chest pain & 1 & 0.9 \\
\hline Slight elevation in liver enzymes & 11 & 7.8 \\
\hline Elevation in lipids & \multicolumn{2}{|l|}{} \\
\hline Slight & 28 & 19.9 \\
\hline$>$ Two times & 1 & 0.7 \\
\hline
\end{tabular}

Systemic side effects were less frequent than mucocutaneous side effects. Of the systemic side effects, lumbar pain was seen in 58 (41.1\%) patients, myalgia in $41(29.1 \%)$ patients, psychological side effects such as stress and nervousness in $34(24.1 \%)$ patients, arthralgia in 27 (19.1\%) patients, headache in 19 (13.5\%) patients, decreased appetite in $23(16.3 \%)$ patients, increased appetite in 8 (5.7\%) patients. Of the biochemical parameters, mild elevation of total cholesterol and/or triglyceride was seen in 28 (19.9\%) patients. In one $(0.7 \%)$ patient, total triglyceride increased more than two fold and it returned to normal when the drug dose was decreased. Liver enzyme levels increased in 11 (7.8\%) patients (Table 3). Systemic side effects were mild and they returned to normal with a decreasing the dose of drug in patients have completed the treatment.

In terms of gender differences, epistaxis was more common in males, but there was not statistically significiant difference $(p>0.05)$, while myalgia and lumbar pain were more common in females $(p=0.045$, $p=0.019$, respectively). When the drug doses were compared, the patients who received higher than $0.5 \mathrm{mg} / \mathrm{kg} /$ day dose had more xerosis, myalgia and triggering acne than those who received less than $0.5 \mathrm{mg} / \mathrm{kg} /$ day $(p=0.004, p=0.001, p=0.012$, respectively). When above 20 years, respectively $\leq 20$ years were compared, myalgia was
Table 4. Findings of statistically significant side effects of isotretinoin according to gender, drug dose and age

\begin{tabular}{|c|c|c|c|c|}
\hline & & $\begin{array}{l}\text { Yes } \\
\text { number } \\
(\%)\end{array}$ & $\begin{array}{l}\text { No } \\
\text { number } \\
(\%)\end{array}$ & p-values* \\
\hline \multicolumn{5}{|l|}{ Gender } \\
\hline \multicolumn{5}{|l|}{ Myalgia } \\
\hline Male & & $5(14.3)$ & $30(85.7)$ & \multirow{2}{*}{0.045} \\
\hline Female & & $36(38.0)$ & $70(62.0)$ & \\
\hline \multicolumn{5}{|l|}{ Lumbar pain } \\
\hline Male & & $8(22.9)$ & $27(77.1)$ & \multirow{2}{*}{0.019} \\
\hline Female & & $50(47.2)$ & $56(52.8)$ & \\
\hline \multicolumn{5}{|l|}{ Dose of drug } \\
\hline \multirow{2}{*}{ Xerosis } & $<0.5 \mathrm{mg} / \mathrm{kg} / \mathrm{day}$ & $18(46.2)$ & $21(53.8)$ & \multirow{2}{*}{0.004} \\
\hline & $>0.5 \mathrm{mg} / \mathrm{kg} /$ day & $75(73.5)$ & $27(26.5)$ & \\
\hline \multirow{2}{*}{ Myalgia } & $<0.5 \mathrm{mg} / \mathrm{kg} / \mathrm{day}$ & $3(7.7)$ & $36(92.3)$ & \multirow{2}{*}{0.001} \\
\hline & $>0.5 \mathrm{mg} / \mathrm{kg} / \mathrm{day}$ & $38(37.3)$ & $64(62.7)$ & \\
\hline \multirow{2}{*}{$\begin{array}{l}\text { Exacerbation } \\
\text { of acne } \\
\text { lesions }\end{array}$} & $<0.5 \mathrm{mg} / \mathrm{kg} / \mathrm{day}$ & $10(25.6)$ & $29(74.4)$ & \multirow[b]{2}{*}{0.012} \\
\hline & $>0.5 \mathrm{mg} / \mathrm{kg} /$ day & $52(51)$ & $50(49)$ & \\
\hline \multicolumn{5}{|l|}{ Age } \\
\hline \multirow{2}{*}{ Myalgia } & Age $14-20$ years & $14(18.4)$ & $62(81.6)$ & \multirow{2}{*}{0.003} \\
\hline & Age $\geq 21$ year & $25(43.1)$ & 33 (56.9) & \\
\hline \multicolumn{5}{|l|}{${ }^{*} p<0.05$} \\
\hline
\end{tabular}

found to be more common in patients older than 20 years $(p<0.05)$ (Table 4). No difference regarding side effects was found between ages and genders in terms of drug dose.

\section{Discussion}

It has been well known that since isotretinoin (13-cis-retinoic acid) is a vitamin A (retinol) analogue, most of the side effects of the drug show side effects similar to hypervitaminosis A syndrome. Isotretinoin has a half-life of 22 hours and a bioefficacy of $25 \%$ and plasma concentrations increase when it is taken with food. Side effects decrease when it is taken twice a day ${ }^{9}$. Side effects are generally grouped into two main groups, mucocutaneous and systemic. The frequency and severity of side effects except for teratogenicity are dependent on dose and they may be controlled with supplementary treatments. These side effects are usually reversible with the discontinuation of the drug ${ }^{6,10}$ When severe side effects are seen, lower doses may be given and in this scenario, a longer period of treatment is required to reach the cumulative dose ${ }^{11}$. In our study, daily dose was given in two doses to decrease the side effects. In addition, the drug was given with meals to increase the absorption of the drug, as recommended. Although 14 of the patients who completed the treatment had a partial recovery, all other patients achieved to have complete recovery. Of the 14 patients who had only partial recovery, 11 were those who were given a high dose $(>0.5 \mathrm{mg} / \mathrm{kg} /$ day) of the drug.

Mucocutaneous toxicity is the most frequent side effect and it is mostly a tolerable and dose dependent effect which responds well to treatment ${ }^{2,9,12}$. Cheilitis is the most frequent side effect of mucocutaneous 
toxicity and it is seen in all patients who receive treatment. Absence of cheilitis is called unsuccessful treatment/accutane failure ${ }^{9}$. Cheilitis incidence is reported as $100 \%$ in previous studies ${ }^{13,14}$. In accordance of previous works, all of the patients in my study had cheilitis. Cheilitis responded well to moisturizing pomades and in severe cases, mild effective corticosteroid pomades also responded well in our study. Xeroderma and dryness in mucosal membranes may be seen in more than half of the cases. In previous studies, frequency of xeroderma has been reported as between $47 \%$ and $85 \%^{14 \cdot 16}$. In my study, frequency of xeroderma was $66 \%$ and it was higher in patients who received high dose drug. Xeroderma was seen more common in winter season in our study and it regressed with topical moisturizers and topical corticosteroids. Symptoms such as feeling of burning and stinging in the eyes due to dryness of the eye, nose and mouth mucosa, nose bleeding and dry mouth-thirst are also common during isotretinoin treatment. Gökalp ${ }^{17}$ found that $41.3 \%$ of the 223 patients with acne vulgaris who were using isotretinoin had mucosa dryness, while $28.7 \%$ had nose bleeding. In our study, xerophthalmia and nose bleeding were found with frequencies of $36.9 \%$ and $42.6 \%$, respectively. Xerophthalmia regressed with synthetic tears, nose bleeding was mild and it regressed with topical moisturizers. Especially in male patients, I observed that when the treatment is given in summer, decreasing the drug dose to less than $0.5 \mathrm{mg} / \mathrm{kg} /$ day may increase patient tolerance.

A deterioration in acne severity may be observed in the first six-week period of isotretinoin treatment in about 6-8\% of the patients, for which discharge of propionibacterium acnes is thought to be responsible ${ }^{18}$. In the present study, a deterioration in acne severity was found to be $44 \%$ of the patients, generally in the first 45 days of the treatment. However, most of these clinical entities were short-term and mild. We did not decrease the dose of the drug. In a few patients, it regressed by adding topical antibiotic creams to treatment.

In patients who use isotretinoin, photosensitivity may be seen if the treatment is in summer season and it generally occurs in the form of erythema on the face. Çııım and Seyhan ${ }^{14}$ reported that $35.1 \%$ of the patients had photosensitivity in their study. In our study, $44.7 \%$ of the patients, especially those who got treatment in summer had photosensitivity and these patients were recommended to use sunscreen regularly.

Arthralgia and myalgia are more common in patients who use isotretinoin and especially in those who have intense exercise. These symptoms may usually be controlled with analgesic drugs ${ }^{19}$. Especially arthralgia is very common and back pain has been reported the most one. Acute arthritis may also be seen and it is reversible, however, in rare cases, it has been reported to continue even years after the treatment is discontinued ${ }^{20}$. In previous studies, back pain has generally been assessed as part of arthralgia. In my study, back pain was assessed as a distinct symptom from arthralgia. Back pain was seen in $41.1 \%$, and arthralgia in $19.1 \%$ of our patients. Myalgia frequency was seen in $29.1 \%$ of my patients and it was more common in females. When the patients compared with regard to lower $(<0.5 \mathrm{mg} / \mathrm{kg} /$ day) and higher dose ( $\geq 0.5 \mathrm{mg} / \mathrm{kg} /$ day) treatment, myalgia was found to be higher in patients who received higher dose than those who received low dose treatment. Myalgia was also higher in patients who were 21 years old and older when compared with those who were younger than 21 years old. Drug dose should be kept low especially in patients who have intense exercise and in athletic patients.
Previous work has shown that mild or moderate increase in liver function tests may be seen in $15 \%$ of the patients ${ }^{20}$. Hyperlipidemia is the most common laboratory side effect in patients using isotretinoin and its frequency may be seen as high as $35 \%{ }^{21}$. After completion of isotretinoin treatment, serum liver function tests and lipid levels return to their normal values in a few months. Blood tests are recommended before treatment and repeated in every 1-2 months. Decrease in drug dosing is recommended when liver function tests increase 2-3 times higher than their normal upper limits. If they do not return to normal despite lower dosing, drug treatment should be discontinued ${ }^{9}$. In our study, total cholesterol and/or triglyceride elevations were seen in 29 (20.6\%) patients. In only one of these patients, total triglyceride levels increased more than two times and it returned to normal when the drug dose was decreased. We stopped treatment in one patient due to elevated liver enzymes more than two times that didn't returned to normal levels with decreasing of the dose. Mild increases were seen in liver enzyme levels in 11 (7.8\%) of patients and these patients were followed more often. Eventually, liver enzyme levels returned to normal levels with temporary decreases in drug dose.

\section{Study Limitation}

In our study, the number of patients using low dose drugs was low. Therefore, we could not make a full comparison between low dose and high dose drug users. There was no follow-up after treatment in our study format. Therefore, the effectiveness of the treatment remains unclear.

\section{Conclusion}

Our study showed that myalgia and lumbar pain is higher especially in female patients. Increase in drug dose will also increase especially xerosis, myalgia and triggering acne complaints. Relatively older patients also experience more myalgia. Since isotretinoin treatment is a long-term treatment, patient tolerance is of paramount importance. Knowing well how frequent side effects occur in different group of patients and informing the patients beforehand will decrease patients' anxiety, increase their confidence in physician and minimize the compliance problems.

\section{Ethics}

Ethics Committee Approval: The study was conducted in line with the Declaration of Helsinki. Ethics board approval was taken from Malatya Clinical Researches Ethics Board (approval number: 2018/27, date: 27.03.2018).

Informed Consent: Written consent was taken from all participants in the study.

Peer-review: Externally peer-reviewed.

Financial Disclosure: The authors declared that this study received no financial support.

\section{References}

1. Tom WL, Barrio VR: New insights into adolescent acne. Curr Opin Pediatr 2008;20:436-40.

2. Brelsford M, Beute TC: Preventing and managing the side effects of isotretinoin. Semin Cutan Med Surg 2008;27:197-206.

3. Layton AM, Stainforth JM, Cunlife WJ: Ten years experience of oral isotretinoin for the treatment of acne vulgaris. J Dermatol Treat 1993;29:2-5. 
4. Geißler SE, Michelsen S, Plewig G: Very low dose isotretinoin is effective in controlling seborrhea. J Dtsch Dermatol Ges 2003;1:952-8.

5. Khatri KA, Garcia V: Light-assisted hair removal in patients undergoing isotretinoin therapy. Dermatol Surg 2006;32:875-7.

6. Feldman S, Careccia RE, Barham KL, Hancox J: Diagnosis and treatment of acne. Am Fam Physician 2004;69:2123-30.

7. İol B, Bulbul Baskan E, Basar Z, Tunalı S, Saricaoglu H: Low Dose Intermittent Isotretinoin Therapy in Moderate Acne Vulgari. Turk J Dermatol 2012;6:7-12.

8. Cunliffe WJ, van de Kerkhof PC, Caputo R, et al: Roaccutane treatment guidelines: results of an international survey. Dermatology. 1997;194:351-7.

9. Ellis $\mathrm{CN}$, Krach KJ: Uses and complications of isotretinoin therapy. J Am Acad Dermatol 2001;45:150-7.

10. Katsambas A, Papakonstantinou A: Acne: Systemic treatment. Clin Dermatol 2004;22:412-8.

11. Kunynetz RA: A review of systemic retinoid therapy for acne and related conditions. Skin Therapy Lett 2004;9:1-4.

12. Scheinfeld N, Bangalore S: Facial edema induced by isotretinoin use: a case and a review of the side effects of isotretinoin. J Drugs Dermatol 2006;5:467-8.
13. Karadag AS, Calka O, Akdeniz N: Evaluation of Side Effects of Isotretinoin in 150 Patients with Acne Vulgaris. Türkderm 2011;45:37-42.

14. Çıkım AÇ, Seyhan M: Efficiency and side effects of isotretinoin usage in the treatment of acne vulgaris. Turkderm 2008;42:51-5.

15. Brito M de F, Sant'Anna IP, Galindo JC, Rosendo LH, Santos JB: Evaluation of clinical adverse effects and laboratory alterations in patients with acne vulgaris treated with oral isotretinoin. An Bras Dermatol 2010;85:331-7.

16. Polat $M$, Öztaş $P$, İlhan $M N$, Allı $N$ : Clinical side-effects and results of systemic isotretinoin treatment in patients with nodulocystic acne. Türkiye Klinikleri J Dermatol 2008;18:72-6.

17. Gokalp H: Isotretinoin Yan Etkileri: [Are the should side effects of isotretinoin limit its use in State Hospital?] Türkiye Klinikleri J Dermatol 2012;22:1-7.

18. Chivot M: [Acne flare-up and deterioration with oral isotretinoin]. Ann Dermatol Venereol 2001;128:224-8.

19. Orfanos CE, Zouboulis CC, Almond-Roesler B, Geilen CC: Current use and future potential role of retinoids in dermatology. Drugs. 1997;53:358-88.

20. Charakida A, Mouser PE, Chu AC: Safety and side effects of the acne drug, oral isotretinoin. Expert Opin Drug Saf 2004;3:119-29.

21. Amichai $B$, Shemer $A$, Grunwald MH: Low-dose isotretinoin in the treatment of acne vulgaris. J Am Acad Dermatol 2006;54:644-6. 